\title{
JUAN GERMÁN ROSCIO Y EL PENSAMIENTO ANTILIBERAL
}

\author{
Carmen Ruiz Barrionuevo \\ Universidad de Salamanca
}

\begin{abstract}
Resumen: En el contexto del reinado de Fernando VII y de la independencia hispanoamericana se analiza el pensamiento antiliberal de Juan Germán Roscio, atendiendo muy especialmente a El triunfo de la libertad sobre el despotismo (1817) y la Homilia del Cardenal Chiaramonti (1817). En estos y otros textos, así como en su epistolario, Roscio hace alusión a algunos de estos clérigos de la época como fray Diego de Cádiz y el obispo Andrés Esteban y Gómez, famosos por sus homilías y predicaciones antiliberales, a los que el prócer venezolano intenta desautorizar.
\end{abstract}

Palabras clave: pensamiento antiliberal siglo XIX, emancipación hispanoamericana, Juan Germán Roscio, fray Diego de Cádiz, fray Andrés Esteban y Gómez.

Abstract: In the context of the reign of Ferdinand VII and the Latin American Independence, Juan Germán Roscio's anti-liberal thinking is analyzed, with particular regard to El triunfo de la libertad sobre el despotismo (1817) and the Homilia del Cardenal Chiaramonti (1817). In these and other texts, as well as in his collection of letters, Roscio refers to some of the clerics of that time, such as fray Diego de Cádiz and Bishop Andrés Esteban y Gómez, both famous for his homilies and anti-liberal preaching, whom the Venezuelan national hero tries to deprive of authority.

Keywords: anti-liberal thinking 19th century, Latin American emancipation, Juan Germán Roscio, fray Diego de Cádiz, fray Andrés Esteban y Gómez.

Los primeros años de la lucha por la emancipación, en los que el venezolano Juan Germán Roscio (1763-1821) acompañó a Simón Bolívar como político y como escritor, fue un periodo conflictivo que marcó para España, Europa y el mundo el paso entre el Antiguo Régimen y la sociedad moderna. El cambio, como es sabido, tiene su vértice en la Revolución francesa y el impulso en los escritores de la Ilustración. Pero a su lado surgirá en paralelo un movimiento antiilustrado que, también de origen europeo ${ }^{1}$, tendrá un gran ascendiente en

1 Véase J. Herrero (Los orígenes del pensamiento reaccionario español, Madrid, Alianza Editorial, 1994) en el apartado "La construcción del mito reaccionario", sobre todo el capítulo dedicado a "Barruel y la reacción europea" (181-218) donde analiza la gran difusión e incidencia del 
España. Si, como indica Javier Herrero, gran parte de la inteligencia europea participa de la Ilustración y se apoya en la razón, en cambio el movimiento antiilustrado "se expresará no mediante argumentos racionales, sino mediante mitos que apelan a las pasiones de las clases reaccionarias, frustradas por el desafío a su autoridad lanzado por los nuevos principios"2. El marco histórico en que se produce este cambio, las Cortes de Cádiz, la guerra de la Independencia y el reinado de Fernando VII, contribuye a cierta peculiaridad en el caso español con el resultado de la división en dos tendencias, una de pensamiento ilustrado, afrancesada o extranjerizante y otra de pensamiento tradicionalista y españolizante. En este último caso una parte de los clérigos de la Iglesia Católica tuvieron una gran influencia en la difusión de esta tendencia, pues las reformas de signo liberal emprendidas después de las Cortes de Cádiz, junto con la invasión napoleónica y más tarde con el trienio liberal, les hicieron percibir amenazado su estatus. Ello les llevó a una identificación de las corrientes ilustradas con las que consideraban fuerzas del mal y a abanderar una serie de mitos $^{3}$ que esgrimieron como enseña frente a los lineamientos liberales y racionalistas.

El pensamiento de Roscio está condensado sobre todo en su decisivo tratado El triunfo de la libertad sobre el despotismo que publicó en Filadelfia en 1817, en el que adoptando el esquema de las Confesiones de san Agustín, desarrolla sus ideas tal y como explicita en el subtítulo: "En la confesión de un pecador arrepentido de sus errores políticos, y dedicado a desagraviar en esta parte a la religión ofendida con el sistema de la tiranía”. En su planteamiento no sólo sostenía su ideario en favor de la emancipación de las posesiones españolas en América, sino que buscaba despejar el camino y vencer la resistencia de cuantos pensaban que el poder real, como derivado de Dios, era intocable para sus súbditos, por lo que no era posible ninguna emancipación de los territorios si ello implicaba una rebelión contra su poder. La vida activa de Roscio se desarrolla casi en su totalidad durante el reinado de Fernando VII, con lo que, dado su pensamiento liberal e ilustrado, sus escritos revelan una constante beligerancia contra el poder despótico del monarca, aunque se pueda contemplar una evolución en su pensamiento desde su época formativa hasta su integración en el proyecto de Bolívar. El propio autor indica que durante un tiempo integró el número de los 'serviles',

pensamiento del jesuita francés en los reaccionarios españoles. En contraste, puede consultarse un análisis acerca de las claves del anticlericalismo en M. Revuelta González, "El anticlericalismo español en el siglo XIX" en Religión y sociedad en España (siglos XIX y XX), Madrid, Casa de Velázquez, 2002, 155-178.

2 Herrero, op. cit., 23.

3 J. Herrero analiza la serie de mitos que entraron en circulación: la conspiración universal de las fuerzas del mal encarnada en los filósofos que adoran la razón para destruir la fe y entregarse al libertinaje; la conspiración de los jansenistas que se planteaban llevar el ideal de libertad a la Iglesia y rebajar el poder papal; la conspiración masónica que se proponía llevar a cabo la entronización de los principios de razón, los derechos humanos y la libertad. Para los reaccionarios y serviles, todas esas conspiraciones se habrían generado en Francia para destruir la civilización europea y los movimientos liberales servirían a esa empresa diabólica. Op. cit., 23-24. 
o absolutistas: "Yo mismo incurrí en esta infamia en 1797 y 1806 ", de lo que se arrepiente con sinceridad:

Menos por malicia que por ignorancia, abusaba de la Religión para sostener la servidumbre de mi patria. Yo fui uno de los que en 1806, tomaron armas y pluma para destruir a los buenos que intentaban conquistar mi libertad y la de mis hermanos [...] Me avergüenzo del servicio especial que hice yo entonces y del mérito que contraje en la opinión del déspota y sus satélites [...] A mucho honor tenía ser esclavo y muy adicto al tirano 5 .

Recordemos que de 1806 data el fracasado intento de Miranda en las costas de Venezuela, fecha que Roscio maneja como el momento en que es partidario de los realistas. Posteriormente tampoco participará en 1808 en el primer intento de revolución en Caracas 6 , aunque dos años después "Roscio y José Félix Sosa fueron los primeros que el 19 de abril de 1810 entraron revolucionariamente en el Cabildo de Caracas titulándose diputados del pueblo" 7 . A partir de este año su actividad en política es continua como también dan cuenta sus escritos. Junto con Martín Tovar y Ponte y Francisco Javier de Ustáriz fue elegido Diputado para el cuerpo conservador de los derechos del señor don Fernando VII, como consta en la Gaceta de Caracas el 20 de octubre de 1810; fue luego Secretario de Relaciones Exteriores de la Junta Suprema de Caracas y poco más tarde redactará con Francisco Isnardy el acta de independencia del 5 de julio de 1811, "Manifiesto que hace al Mundo la Confederación de Venezuela". A partir de este momento empieza a desplegarse con gran fuerza su pensamiento en múltiples escritos evidenciando una continuada reflexión, tanto en sus textos oficiales y personales como en su epistolario.

La idea central que rige su obra gira en torno a una obsesiva preocupación, la de observar que en los territorios de América el ciudadano de su tiempo se encuentra "encorvado bajo el triple yugo de la monarquía absoluta, del fanatismo religioso y de los privilegios feudales", y más concretamente, la implica-

4 J. G. Roscio, El triunfo de la libertad sobre el despotismo, prólogo, cronología y bibliografía de D. Miliani, Caracas, Biblioteca Ayacucho, 1996, 10.

5 Ibid., 234.

6 Ibid., 10. Augusto Mijares señala: "Tampoco figura Roscio entre los que en 1808 promovieron el primer intento de revolución en Caracas, pero veremos cómo, después, afirma reiteradamente que en aquel año debió Venezuela declararse independiente, lo cual indica que era ya revolucionario convencido si no activo". En J. G.Roscio, Obras, 3 vols., prólogo de A. Mijares, compilación de P. Grases, Caracas, Publicaciones de la Secretaría General de la décima Conferencia Interamericana, 1953, XX.

7 Mijares en Roscio, ibid.

8 Estos y otros datos biográficos pueden consultarse en el trabajo de Mijares (ibid., XX-XXII) y en la cronología de D. Miliani, en Roscio, 1996, op. cit., 263-271. Los documentos relacionados con esta época pueden verse en la compilación Pensamiento politico de la emancipación venezolana.

9 Una frase similar aparece en una carta a su amigo Martín Tovar que data de 1816, donde pide la libertad para "todos aquellos que como nosotros gimen bajo el triple yugo de una monarquía 
ción entre el poder político y la religión en la España de su tiempo, una alianza que incidía de manera notable no solo en los objetivos de la emancipación de los territorios americanos, sino en la libertad individual de los individuos, abiertamente menoscabada por el poder absoluto. Porque, como resulta evidente, la mayor parte del estamento religioso se identificó con el poder absolutista del monarca compartiendo y difundiendo sus ideas y contribuyendo a la propaganda realista, con lo que gran parte de los clérigos llegaron a bendecir ciegamente el poder real y así Fernando VII contó con una jerarquía eclesiástica ampliamente colaboradora ${ }^{10}$. "De ahí el interés del rey en que le fueran adictos los obispos y superiores religiosos. El derecho de presentación de los obispos facilitaba mucho la cuestión, ya que durante la guerra habían quedado muchas diócesis vacantes y quedarían otras durante el sexenio"11. Ello implicaba también un rechazo total al pensamiento liberal, contexto en el que se desarrolla el pensamiento de Roscio, que liberal e ilustrado, demuestra claramente en sus lecturas su deuda intelectual con los pensadores franceses. Recordemos que la vuelta de Fernando VII en 1814, después del fracaso de la invasión napoleónica, supone la vuelta al absolutismo hasta 1820, año en que comienza el trienio liberal. En consecuencia, la mayor parte de la gestión pública de Roscio, fallecido en 1821, se cumple bajo la opresión absolutista. Por estas razones resulta de interés seguir su planteamiento frente al problema de la difusión del pensamiento antiliberal a través de sus escritos, muy fundamentalmente en dos de sus publicaciones, su libro El triunfo de la libertad sobre el despotismo y la Homilía del Cardenal Chiaramonti, obispo de Imola, actualmente sumo pontífice Pio VII, que Roscio publica con una muy clara intención, desacreditar la influencia de la iglesia española en el objetivo de la independencia.

Parece claro que de una manera u otra hasta 1809, Roscio sostenía una convicción partidaria del poder real al servicio de la Corona, aunque posteriormente se arrepintiera de su postura, tal y como explicita en el Prólogo del Triunfo de la libertad sobre el despotismo. Este tratado doctrinal, largamente meditado, y del que tenemos testimonio de su interés en difundir como instrumento de persuasión para la emancipación de los territorios, plantea, después del fracaso de la Constitución de Cádiz, la defensa de la libertad y el derecho de los pueblos a su emancipación, negando el derecho divino de los reyes y aventurando incluso la

absoluta, del fanatismo religioso, y de los derechos feudales". Roscio, 1953, op. cit., 52 .

10 El trabajo de Manuel Teruel, Obispos liberales. La utopía de un proyecto (1820-1823) (Lleida, Editorial Milenio, 1996), aborda este aspecto para con concluir que "la línea de actuación de los obispos ilustrados del siglo XVIII se truncó al perderse la oportunidad de cubrir sedes episcopales con unos liberales que podrían haber sido sus continuadores natos. Al frustrarse, pues el intento de creación de un episcopado liberal -de liberales tal vez sería más exacto- se produjo una regresión en los valores de la jerarquía española que, salvo excepciones, se prolongará en el XIX y el XX" (273-274).

11 F. Martí Gilabert, Iglesia y Estado en el reinado de Fernando VII, Pamplona, EUNSA, 1994, 25-26. 
posibilidad del regicidio ${ }^{12}$. Con esta intención su autor desarrolla una interpretación de la Biblia que contradecía la vigente en el catolicismo de su época: "Me dediqué al estudio de la Vulgata, no en los indigestos y dolosos comentarios que me llenaron el tiempo, mientras yo cursé la cátedra de escritura, sino como debieron estudiarla los autores de ellos, y como la estudia quien no está consagrado en cuerpo y alma al servicio de la tiranía". Y concluirá una y otra vez en todos los aspectos estudiados que no existe ninguna "ley del nuevo y viejo Testamento que favoreciese la opresión"13 porque los usos de la monarquía absoluta y despótica no pueden conciliarse de ningún modo con el cristianismo.

Entre 1810 y 1812 Roscio mantiene una importante e ilustrativa correspondencia con Andrés Bello, seis cartas en total fechadas de 1810 a $1812^{14}$, en la que se denota la preocupación por diferentes aspectos de la guerra en curso, aunque no existe en ellas todavía el tratamiento en profundidad del tema que proponemos, el de la persistente campaña absolutista planeada por los clérigos antiliberales. Sin embargo Roscio estaba ya en esos años muy implicado en los aspectos políticos, como lo indican estas cartas y otros documentos, como el titulado " $\mathrm{Pa}$ triotismo de Nirgua y abuso de los reyes" publicado en el Gaceta de Caracas en 1811 y que Domingo Miliani considera "el antecedente conceptual y estructural inmediato de El triunfo de la libertad sobre el despotismo"15, puesto que ya defiende la idea del regicidio contra los malos monarcas. Incluso en esas mismas fechas, en cartas como la dirigida a Blanco White ${ }^{16}$, no aparece de forma explícita esta preocupación. Solamente a partir de 1816 cuando Roscio ha experimentado duros avatares personales en América y en España se consolida esta idea. Así el 16 de junio de 1816 escribe desde Kingston, Jamaica, de paso para Filadelfia, a su amigo Martín Tovar, una carta en la que centra su preocupación fundamental: la de difundir por escrito, y mediante un tratado, sus ideas en torno a la emancipación del mundo americano; algo que ya había redactado en prisión - señalemos que Roscio fue apresado con otros compañeros en 1812, llevado a Cádiz y luego trasladado a la cárcel de Ceuta, de donde logra salir en 1815 gracias a las gestiones del liberal británico Thomas Richards-. Por eso le confía a Martín Tovar que su objetivo preferente es reunir todas aquellas ideas que "tienen por objeto el combatir los errores religiosos y políticos que afianzan

12 Roscio, 1996, op. cit., 3.

13 Ibid., 4.

14 Las cartas a Bello están fechadas del 29 de junio 1810 al 10 de marzo de 1812, y en ellas trata diferentes aspectos de la situación política del momento: estrategias, personas, publicaciones, o un par de significativas referencias a El Español de Blanco White. Roscio, 1953, op. cit., III, 3 y ss.

15 Miliani en Roscio, 1996, op. cit., XXI.

16 Roscio escribe a Blanco White una carta el 28 de enero de 1811 donde le expresa su agradecimiento por el apoyo que El Español significa en la empresa de la emancipación y le pide que siga divulgando las verdaderas noticias con el fin de contrarrestar las difundidas por los enemigos. Roscio, 1953, II, 212-214. 
la tiranía y la servidumbre"17, factores que incidían gravemente en las fuerzas integrantes de los ejércitos, como bien confía a su amigo ${ }^{18}$. El gran problema que se le presentaba, según razona, para conseguir sus objetivos, residía en que los nacidos en América eran, en este sentido, más vulnerables que los propios españoles, ya que "Por las falsas ideas de religión y política que aprendieron desde la cuna, y mediante las cuales creen que es un atentado contra Dios, y su santa religión el levantarse contra el despotismo español, desprenderse de él, y fundar el sistema de la independencia" ${ }^{19}$, no se atreverían a contradecir los designios y la potestad real. Todo le lleva a su autor a sentenciar que no hay un "gobierno más arbitrario, e infernal que el de España" pues se trata de una "monarquía absoluta, sin leyes, sin constitución, sin religión", en la que cualquier cosa "depende del capricho y albedrío de un solo individuo, por lo común, tonto, preocupado y malvado" 20 , un gobernante que además exhibe hipócritamente el respeto a las leyes pero que se lanza en manos de religiosos y devotos. Es en este momento, tal vez por la experiencia que tuvo de forma directa en su prisión en España, cuando el venezolano despliega con amplitud algunos datos sobre la gran importancia de la imprenta en la difusión de las doctrinas de ese pensamiento servil y reaccionario:

Sabe el gobierno español que ellas son el fundamento de su tiranía y de su duración. Bajo este concepto reproducen, imprimen y reimprimen libros, y folletos religiosos políticos alusivos a sus miras, y premian con muy buenas pensiones y beneficios a los frailes, y clérigos que en el púlpito, en las cátedras, confesiones periódicos etc., esparcen, predican y fomentan esta infernal teología política ${ }^{21}$.

Y es que Roscio, al escribir a Martín Tovar, está todavía bajo el impacto de uno de los casos que conoció en el momento de su salida de España y que más le conmovió, la homilía de un obispo español que conoció impresa en noviembre de 1815, una plática realizada "en hacimiento de gracias a Dios por el asesinato jurídico del virtuoso coronel Porlier"22. Se trata de la misma homilía a la que alude extensamente en el "Apéndice" de su obra magna, El triunfo de la libertad sobre el despotismo, un libro que, en ese momento, al pasar por Kingston,

17 Ibid., III, 46.

18 En este momento cuenta una anécdota que llegó a su conocimiento acerca de que los soldados que integran los ejércitos realistas eran en su mayoría americanos porque, como dice su interlocutor: “¿Qué quiere Ud. que hagan, si todos están pensando que Fernando VII es Dios?". Ibid., 46.

19 Ibid., 46-47.

20 Ibid., 49. Se insiste en varios lugares en la absoluta carencia de religión de Fernando VII ofreciendo ejemplos como la presión ejercida a EEUU, mediante la cual insta a su gobierno a perseguir a los insurgentes mexicanos con amenazas a su economía (id., 51-52).

21 Ibid., 47.

22 Ibid. 
llevaba ya escrito para publicar en Filadelfia y que, tras el impacto de la homilía se verá obligado a prolongar con un amplio apéndice comentando la homilía por extenso, y a la que más adelante nos referiremos.

La carta de Roscio a Martín Tovar puede leerse como un antecedente de algunas de las ideas troncales de su libro, ya que nos explica los resortes y las circunstancias, y sobre todo el objetivo que perseguía con su obra, pues, según el autor, la refutación de las ideas absolutistas debía hacerse con decisión pero también con un conocimiento exhaustivo de los textos religiosos, porque para impugnarlas "de manera que muestre[n] el fraude y la trampa, es menester estar perfectamente instruido en el sistema sofístico, y doloso de los oradores de la monarquía absoluta, y muy versado en los libros de la religión y gobierno"23. Eso es justamente lo que hace al publicar El triunfo de la libertad contra el despotismo donde prima la descalificación de los procedimientos del pensamiento de los clérigos absolutistas que tanto influían en la población en favor del despotismo de Fernando VII. Usar la Biblia y pasajes esenciales del Antiguo Testamento para demostrar que en el pueblo residía la soberanía, era en esa época algo sumamente atrevido y destinado al fracaso, ya que la Iglesia y los clérigos absolutistas capitalizaban casi todo el espacio público. Una de las figuras antiliberales que le obsesiona en este libro es el autor de un folleto aparecido en 1814, al que alude en un primer momento sin nombrarlo que "enseñaba ser peculiar de los Reyes el poder y la fuerza" 24 y otros instrumentos que fortalecían el despotismo frente al pueblo, pero que páginas más adelante concreta:

Este impreso es uno de los muchos que han salido de las prensas de Madrid después del 4 de Mayo de 1814, en apoyo de la tiranía. Es un volumen compuesto de varias cartas, que se dicen escritas por Fr. Diego de Cádiz a un sobrino suyo, que militaba en la Península contra los ejércitos de la República Francesa instruyéndole en las obligaciones de un soldado cristiano ${ }^{25}$.

Roscio se refiere a fray Diego José de Cádiz (1743-1801), misionero capuchino, fiel representante del clero reaccionario de la época, que con su palabra vehemente conmovía a los creyentes por diversos lugares de España, sobre todo por Andalucía, aferrado a la intransigencia en materias de doctrina y de moral. Su "enorme energía que hizo de él el predicador más famoso de su época, su mezcla de rigor moral e implacable agresividad y su odio inextinguible a las doctrinas del siglo hacen de él uno de los más importantes hombres de acción del último tercio del siglo XVIII" ${ }^{26}$. De influyente oratoria, en una sociedad carente de educación, defendía el absolutismo frente a cualquier resquicio liberal

23 Ibid., 48.

24 Roscio, 1996, op. cit., 116.

25 Ibid., 197.

26 Herrero, op. cit., 142. 
en costumbres y pensamiento ${ }^{27}$. Con gran ascendiente en las multitudes, debía ser harto conocido para el venezolano por su popularidad en aquella época en la que Roscio pasó preso en Cádiz y Ceuta. Fray Diego atacó a las representaciones teatrales ${ }^{28}$, a las personas de alcurnia, a las instituciones de la Corona y a las que asumían algún progreso, que pensaba contagiado de los revolucionarios franceses a los que consideraba "hijos de Lucifer". Fue, en definitiva, un excelente representante del clero reaccionario de la época, y aunque fue perseguido por los mandatarios también salió triunfante y fue apoyado por sus seguidores ${ }^{29}$. No se engañaba Roscio al levantar con ironía la sospecha: "Yo no sé por qué causa han estado inéditas estas cartas desde 93 o 94 del siglo pasado hasta $1814 " 30$. En efecto, Fray Diego escribió El soldado católico en guerra de religión ${ }^{31}$, para la guerra franco-española de la Convención (1793-1795) que terminó degradantemente para España con la Paz de Basilea, y recuperado el texto posteriormente, será esgrimido por sus partidarios de 1808 a 1814 en la lucha

27 Un interesante estudio sobre su figura puede consultarse en M. V. López-Cordón ("Predicación e inducción política en el siglo XVIII: Fray Diego José de Cádiz”, Hispania, 138, eneroabril 1978, 71-119), donde se ofrecen abundantes datos de su biografía, predicaciones, escritos, polémicas y enfrentamientos con el poder. Fray Diego se convirtió en el "paladín de la antiilustración: los teatros, las nuevas doctrinas económicas, el 'afrancesamiento' de las costumbres y, sobre todo, el laicismo imperante, encontraron en él una actitud combativa y hostil que supo comunicar a muchos de sus contemporáneos" (80-81). El incidente más conocido de su vida es el caso de la denuncia al profesor Lorenzo Normante en Zaragoza, sobre el que llamó la atención J. Sarrail (España ilustrada de la segunda mitad del siglo XVIII, México/Buenos Aires, Fondo de Cultura Económica, 1957, 278-280) y que analizan Herrero (op. cit., 142-147) y sobre todo López-Cordón (op. cit., 104-109) y en su relación con el sermonario gaditano de la época J. Romero González ("El sermonario gaditano en la segunda mitad del siglo XVIII. Una sociedad en cambio" en P. Fernández Albadalejo y M. Ortega López, eds., Antiguo Régimen y liberalismo. Homenaje a Miguel Artola. 3. Politica y cultura, Madrid, Alianza Editorial, 1995, 615).

28 "Sus diatribas contra las comedias, que le dan fama, le ocasionan algunos problemas con las autoridades, pero casi siempre el triunfo sobre sus detractores era rotundo y terminaba logrando que los Ayuntamientos se comprometieran, mediante juramento y acta capitular, a no permitir aquella clase de espectáculos”. López-Cordón, op. cit., 77.

29 En 1784 se le acusó de atentar contra los derechos del rey a consecuencia de un sermón en la Catedral de Sevilla, aunque salió bien parado "ya que contaba con el apoyo casi unánime de los miembros de su estamento, que se apresuran a encubrir sus palabras y que lograron detener el proceso. Entonces, como más adelante, las relaciones ganadas en la corte y la política en torno al confesor regio dieron su fruto, así como la hostilidad de ciertos sectores hacia la política reformista de Consejo de Castilla”. Ibid., 104.

30 Roscio, 1996, op. cit., 198.

31 Fue dirigido en forma de carta a su sobrino Antonio, enrolado como voluntario en el ejército. Las primeras ediciones aparecieron en 1794 en Écija y Barcelona. El texto fue reimpreso en la guerra de la independencia y al menos se conservan ediciones de los años 1813 en Cádiz, 1814 en Madrid, y 1815 en Córdoba. Hemos consultado la siguiente edición: El soldado católico en guerra de religión. Carta instructiva ascética-histórico-politica en que se propone a un soldado católico la necesidad de prepararse, el modo con que lo ha de hacer, y con que debe manejarse en la actual guerra contra el impio partido de la infiel, sediciosa y regicida Asamblea de la Francia [...]. Reimpreso en Cádiz en la Casa de Misericordia, Año 1813. 
contra los ejércitos napoleónicos. Puede aplicarse a fray Diego lo que ha señalado Peñas Bernaldo de Quirós acerca de la situación en la península: "Una parte de la inteligentsia del Antiguo Régimen, identificada con el pensamiento reaccionario desde la guerra de la Convención (1793-1795), inicia una virulenta campaña propagandística dirigida a las capas populares" 32 con el esquema preconcebido de considerar a la invasión francesa un producto de una conjura internacional con su vértice en las ideas de la Revolución francesa y un desarrollo en las creencias masónicas que capitalizarían Napoleón en Europa y en España Manuel Godoy. Así el conflicto se convertirá en cruzada contra el invasor y también contra las ideas ilustradas liberales. "En consecuencia, se establece un paralelismo entre filosofía, ateísmo, herejía, satanismo y blasfemia” cuya popularización "evoluciona a una ideología intransigente y exterminadora, que viene a destruir la labor de progreso material y cultural de la ideología ilustrada y el reformismo del Despotismo Ilustrado"33. Dentro de esta línea se incluye este tratado, el más conocido de fray Diego, cuyas ideas antiilustradas no son más que una vulgarización de las del fray Fernando de Zeballos ${ }^{34}$, a quien cita con frecuencia en sus escritos para teorías y opiniones, pues la cultura del autor no rayaba a gran altura ${ }^{35}$.

Muchas de las ideas de este tratado debieron ofender al venezolano pues en él se exhibe una total confusión entre la misión bélica y política del soldado y su relación con la fe, así, en un momento determinado se señala que la deserción se parangona con la apostasía de la fe religiosa, pero Roscio únicamente extrae una de las frases en la que se enfatiza la relación con el rey desde esa perspectiva de su carácter divino: "No quedará sin castigo (dice el texto), quien ofendiere al Rey, aunque no sea más que con el pensamiento" ${ }^{36}$, ya que afectaba directamente al tema de la soberanía del pueblo que el autor sustentaba en su libro.

32 J. C. Peñas Bernaldo de Quirós, "El pensamiento reaccionario en las Cortes de Cádiz”, en P. Fernández Albadalejo y M. Ortega López, eds., Antiguo Régimen y liberalismo. Homenaje a Miguel Artola. 3. Politica y cultura, Madrid, Alianza Editorial, 1995, 541.

33 Ibid., 542. Este autor ofrece exponentes y obras de ese pensamiento de nacionalismo tradicional que es defendido tanto desde el púlpito como desde medios como El diario político de $M a-$ llorca, El diario de Santiago, El patriota compostelano y otros. "No es envidiable la posición de estos liberales de raigambre ilustrada entre 1808 y 1814 . Estos, deben luchar contra la opinión popular 'reeducada' por el pensamiento reaccionario, que achaca las desgracias nacionales a cualquier corriente renovadora de concomitancia con la vecina y enemiga Francia. Id., 545.

34 Herrero, op. cit., 91-104.

35 Otro predicador sumamente conocido, al que Roscio no alude, es el padre Rafael Vélez, también de la orden de los capuchinos, que en el Cádiz de 1812 y 1813 difunde sus sermones, "A través del diario reaccionario El sol de Cádiz, y su libro El preservativo contra la irreligión, da rienda suelta a su teoría de que España es un país dechado de virtudes, de catolicismo y monarquismo inmaculado, que está siendo envenenado por las ideas ilustradas" (Peñas, op. cit., 548). Obra suya es el tratado reaccionario más extenso: Preservativo contra la irreligión, o los planes de la filosofía contra la religión y el estado, realizados por la Francia para subyugar la Europa, seguidos por Napoleón en la conquista de España y dados a luz por algunos de nuestros sabios en perjuicio de nuestra patria (1812).

36 Roscio, 1996, op. cit., 198. 
Que el folleto le había impactado lo prueba el que vuelva a citarlo en un artículo posterior titulado "Catecismo" que publica en $1819 \mathrm{y}$ al que posteriormente haremos alusión.

Sin embargo resultan aún más contundentes sus argumentos, y más amplios, en el "Apéndice" de El triunfo de la libertad contra el despotismo, en este caso contra otro de los abanderados del pensamiento antiliberal, Andrés Esteban y Gómez (1814-1817), obispo por entonces de Ceuta, uno de los más beligerantes prelados absolutistas, autor de varios textos en esa línea y en particular de la homilía que conoció Roscio al salir de España, la dedicada al caso del General Juan Díaz Porlier. No parece que nuestro autor hubiera oído hablar previamente, ni escuchado noticia de alguna de las predicaciones del obispo de Ceuta, ya que no deja constancia de ello, aunque los años de obispado de Esteban y Gómez coinciden con los de la prisión del venezolano en $\mathrm{Ceuta}^{37}$. Al contrario, en la carta a Martín Tovar antes citada, resume con cierto detalle su reacción y el contexto en que lo conoció:

Luego que recibimos en Gibraltar un ejemplar de la homilía de aquel infame adulador prelado, contesté yo una carta particular, insertando en ella una refutación compendiosa, que comenzaba así: 'Si la religión santa que consagra del modo más sublime y celestial la majestad y soberanía de los pueblos, los derechos imprescriptibles del hombre, fuese capaz de estremecerse, se estremecería al oír las blasfemias y disparates, que incluye el discurso que hizo el obispo de Ceuta el día 12 de Noviembre de 1815 en su iglesia catedral dando gracias a dios por el asesinato jurídico del virtuoso general Porlier', No dude Ud., mi querido Tovar, que esa religión del obispo de Ceuta, es la religión de Fernando VII, de la mayor parte de la España, y de todos nuestros hermanos americanos los que se hayan en actual servicio de este tirano. Esta es la religión del presbítero Maya, del presbítero Torreyes, del presbítero Fr. Pedro Hernz del presbítero Llamozas, Rojas y demás clérigos y frailes serviles que han coadjuvado a los triunfos de Monteverde, Boves, Zuazola, Rosete, Morales, Morillo, etc. ${ }^{38}$

Sin embargo, al gozar de más espacio en el "Apéndice", el tema se presenta en toda su extensión y puede aludir con amplitud a ese impreso de la homilía que

37 “D. Andrés Esteban y Gómez había sido canónigo de la catedral de Sigüenza, y en 1808 ocupó el cargo de vocal secretario de la Junta de Defensa de Guadalajara y fue elegido diputado de las Cortes de Cádiz. Por sus ideas antiliberales hay que adscribirlo al grupo absolutista. Nombrado obispo de Ceuta en 1814, tomó posesión de la diócesis de Jaén en julio de 1816, donde residió hasta su muerte acaecida en 1831" (A. Moliner, "El antiliberalismo eclesiástico en la primera restauración absolutista (1814-1820)" en Hispania Nova, revista de Historia Contemporánea, 3, 2003, http://hispanianova.rediris.es/articulos/03_012.htm.). El mismo autor analiza la Exhortación pastoral que escribió en abril de 1816: tiene como único objeto combatir "las doctrinas falsas y subversivas de los presentes tiempos" en el momento en que estaba recién nombrado para la sede de Jaén, obra que puede consultarse en la Colección Documental del Fraile, Archivo Histórico Militar de Madrid.

38 Roscio, 1953, op. cit., III, 51. 
circula por España después de la muerte del General Porlier ${ }^{39}$, en el que su autor aplaudía al monarca por su acción y tras un Te Deum en la catedral de Ceuta: "Ya teníamos escrita nuestra confesión, cuando circulaba en España un impreso, cuya lectura nos obligó a este suplemento" ${ }^{40}$. El prócer venezolano exhibe en este apéndice un completo planteamiento del problema, pues esta actuación del obispo de Ceuta como la de fray Diego de Cádiz pueden extrapolarse a todos los territorios españoles, incluso al territorio venezolano y las razones aducidas en la homilía coinciden con las que su autor desea refutar. Una frase del obispo de Ceuta, que también reproduce en la carta a Martín Tovar, es el punto de partida: "La religión santa, que consagra del modo más sublime y celestial, las personas y derechos de los soberanos de la tierra, se estremeció al grito de independencia y de arrojo, que dio este genio desgraciado, con un fuego devorante" ${ }^{41}$, es decir, que Esteban y Gómez deja sentado que la soberanía reside únicamente en el rey, que puede gobernar despóticamente sin contar para nada con su pueblo, porque, según los clérigos absolutistas, es la Religión la que rige toda la vida del hombre, ya que de hecho, y en algunos importantes momentos históricos, los pontífices han consagrado a los monarcas. Esta es la ocasión en la que Roscio aprovecha para hacer ver que esa costumbre no está asentada en las Escrituras y que casos como el de Napoleón, en ese momento confiado en Santa Elena, demuestran que la degradación de los monarcas se puede realizar según las leyes humanas, sin obstáculo de las divinas. En todo momento el venezolano insiste en la necesidad de separar la religión y el estado, y dejar sentado cuáles son las "relaciones que mutuamente enlazan al súbdito y al soberano", relaciones "emanadas todas del contrato social: relaciones de un orden superior a las que ligan al gobernante con su gobernado. Nada hay en ellas de sagrado y divino, bajo la idea con que se explica su señoría ilustrísima: porque son falsos todos sus fundamentos" ${ }^{2}$. Está bien clara la distancia que separaba al prócer venezolano del pensamiento servil, incluida la referencia a El contrato social de Rousseau, por lo que puede permitirse incluso a continuación algunas ironías y desafíos: "Yo quisiera saber, cuándo fue que nació la religión que en dictamen del Obispo nos inspira un amor sagrado hacia los Reyes y autoridades supremas" 43 , para después de valorar las posturas con los principios de las Escrituras, y terminar con una arenga a los españoles para que imiten las virtudes de Porlier y consigan la dignidad de hombres libres: "Así, borrada la nota de vasallos españoles, trans-

39 El general Juan Díaz Porlier fue apresado después de su pronunciamiento liberal el 18 de septiembre de 1815 y luego ahorcado. Con fecha de 12 de noviembre de 1815 el obispo Andrés Esteban y Gómez imparte una homilía en la Catedral de Ceuta en la que se refiere al suceso. "La imprenta de Algeciras tuvo la desgracia de multiplicar y propagar ese discurso”. Roscio, 1996, op. cit., 245 .
40 Ibid., 244.
41 Ibid.
42 Ibid., 251.
43 Ibid., 254. 
mitiréis a vuestra descendencia la dignidad de hombres libres"44. En definitiva, su autor emplea el mismo procedimiento pormenorizado que aparece en el tratado precedente al analizar la "infame homilía", muy en especial en alguno de los párrafos que logró copiar del original, para demostrar que la religión nunca puede ser tiranía y que la soberanía reside en el pueblo según los textos sagrados y nunca en los monarcas opresores.

En el mismo año 1817, un nuevo texto del venezolano se hace eco del problema, pues publica la Homilia del Cardenal Chiaramonti, obispo de Imola, actualmente sumo pontífice Pio VII ${ }^{45}$ y aunque el título no expresa la autoría de Roscio, después del prólogo del traductor francés, se introduce un "Prólogo del traductor español", que es obra suya y en el que sitúa no sólo este texto sino una carta exhortatoria del pontífice, más reciente, que contiene afirmaciones que a Roscio le interesa contrastar con la primera aparecida en 1797:

En la Gazeta de Puerto Rico de 17 de Mayo del corriente aparece inserta una carta del mismo Pontífice en favor del actual rey de España y contra los insurgentes de la América antes Española. En esta carta se suponen pecaminosas las conmociones de estos países, y como tales se procuran calmar de un modo ignominioso a la dignidad del hombre. Se suponen contrarias a la Santísima Religión que profesamos y sembradas por el hombre enemigo. Se atribuyen a Fernando VII virtudes ilustres, y singulares, y se avanzan otras proposiciones agenas [sic] a la verdad, y opuestas al derecho natural y divino de las Américas ${ }^{46}$.

En realidad este segundo texto presentado por Roscio era la encíclica Etsi longissimo terrarum ${ }^{47}$ que el papa Pío VII (1742-1823) publicó el 30 de enero de 1816, en la que exhortaba a los clérigos americanos de las posesiones españolas a controlar la rebelión contra la monarquía creyéndola promovida por fuerzas de origen masónico originadas en las revoluciones europeas ${ }^{48}$. Este ambiente provoca claramente la necesidad de Roscio de traducir y publicar los citados textos papales, pues pretendía evidenciar la falsedad de lo más peligroso para los intereses emancipadores, que era claramente la última encíclica. Una carta que

44 Ibid., 258.

45 El título completo es Homilia del Cardenal Chiaramonti, obispo de Imola, actualmente sumo pontífice Pio VII, dirigida al pueblo de su diócesis en la república cisalpina, el día del nacimiento de JC, año 1797, traducida del italiano al francés por el Sr. Henrique Gregoire, obispo de Blois, y del francés al español por un ciudadano de Venezuela en la América del Sur, que la publica rebatiendo con ella un papel del mismo papa, en favor de Fernando VII, contra los insurgentes de las llamadas colonias españolas.

46 Roscio, 1953, op. cit., II, 105

47 Anota Miliani citando a Luis Ugalde: "el Embajador de España ante la Santa Sede, Vargas Llaguno, consiguió 'que el Papa aceptara convertir en encíclica condenatoria de la independencia un documento básicamente redactado por él”' (Miliani en Roscio, 1996, op. cit., 268).

48 Como consecuencia "Se nombraron 28 obispos para América, que debían atender a las necesidades espirituales, pero también fomentar la sumisión al rey legítimo” (Martí Gilabert, op. cit., 178). 
entraba dentro de la campaña antiliberal y antiemancipadora que había emprendido el clero de la época, por lo que Roscio alude con ironía a su carácter apócrifo, porque está "dirigida al clero secular y regular de la América insurrecta, con fecha de 30 de enero de 1816 y publicada en Caracas a 15 de febrero del presente año por uno de los aduladores más serviles de la tiranía española”, se refiere desde luego al Vicario General don Manuel Vicente de Maya (17671826) ${ }^{49}$ que gobernaba la diócesis de Caracas bajo el mandato del Arzobispo Narciso Coll y Prat (1754-1822) ${ }^{50}$. En ella se insta a los sacerdotes para que contribuyan al orden y las buenas costumbres con el cese de las revueltas presentando las

ilustres y singulares virtudes de nuestro carísimo hijo en Jesucristo, Fernando vuestro rey católico, para quien nada hay más precioso que la religión y felicidad de sus súbditos" [por lo que]A consecuencia de esta paternal exhortación [...] yo solo debía añadiros las expresiones de que usaban los profetas para anunciar a los pueblos las más importantes verdades; Dios ha hablado; es forzoso obedecer ${ }^{51}$.

Roscio aduce con habilidad al texto para destacar que resulta poco creíble la autoría papal, dada la homilía que escribió como Obispo de Imola y que reproduce en primer lugar ${ }^{52}$ y que se trata del Pío VII, un pontífice voluble pues fue el mismo que ungió a Napoleón ${ }^{53}$ y ha lanzado gran cantidad de lisonjas a Fernando VII, aunque "Todo el mundo sabe quien es el rey de los Españoles: un mal hijo, un mal hombre, ingrato y pésimo monarca" ${ }^{54}$. Por otro lado afirma que "el provisor de Caracas [Manuel Vicente Maya, está] más interesado que

49 Manuel Vicente de Maya fue sacerdote y político, miembro del congreso y firmante el 5 de julio de 1811 del Acta de Independencia. Aunque fue el único que votó en contra, acató la decisión de la mayoría. Firmó diversos documentos y pastorales en su calidad de canónigo magistral atacando a la masonería y encareciendo la conveniencia de mantenerse fieles a Fernando VII.

50 Narciso Coll y Prat fue el segundo Arzobispo de Venezuela. Vivió difíciles situaciones derivadas del Primer Congreso venezolano que declaró la independencia el 5 de julio de 1811. Permaneció en la capitanía general de Venezuela seis años. En 1816 por denuncia del general Morillo es remitido a España, donde tuvo que rendir un informe detallado de su actuación. Aunque fue exonerado y se le ordenó trasladarse a Madrid con la autorización de regresar a Venezuela, lo impiden el triunfo de los republicanos en Carabobo el 24 de junio de 1821 y otros contratiempos personales. Falleció en Madrid el 28 de diciembre de 1822.

51 Roscio, 1953, op. cit., II, 133.

52 Mijares hace notar que no demuestra mucho entusiasmo por la libertad en la primera homilía y que en 1797, como obispo de Imola, se vio obligado a defender ideas liberales, por lo que se sale "por la tangente dejando entrever que la necesidad de obedecer la soberanía temporal puede invocarse en todo caso" (Mijares en Roscio, ibid., I, LIX).

53 Pío VII coronó a Napoleón el 2 de diciembre de 1804. "El mismo predicador que hoy aplaudía y ensalzaba la real autoridad de este nuevo monarca, mañana hablaba el mismo lenguaje en honor de su competidor, si era preponderante su partido" (Roscio, ibid., II, 110).

54 Ibid., 112. 
ningún otro en lisonjear las pasiones del tirano"55. Roscio empleará el mismo procedimiento que en su libro, demostrar que nada se contradice con la religión cristiana y que al contrario, el cristianismo hace un gran bien a la república, ya que además muchas naciones cristianas han ejercido el mismo derecho que los países de América, incluso la propia España desde la época del imperio romano. En definitiva, Roscio pretende hacer notar el contraste entre ambos textos y descalificar su autoría. El primer texto, la homilía impartida por Pío VII cuando era obispo de Imola, se apoyaría en la idea de que en las máximas evangélicas está la igualdad y la "libertad discreta" y que ello "asegura la existencia, y el honor de la Democracia", por eso dice el obispo Chiaramonti: "Esforzáos por llegar a toda la altura de la virtud, y vosotros seréis verdaderos demócratas; cumplid fielmente los preceptos evangélicos, y seréis el júbilo de la República”" ${ }^{56}$, frente al segundo texto que se presenta como absolutamente partidario y reaccionario.

Quien clamaba tan radicalmente contra los clérigos serviles era sin embargo cristiano, y así se declaraba en su testamento dado el 14 de abril de 1818, aunque añadía a su lado su profesión republicana: "declaro y confieso que profeso la religión Santa de Jesucristo, y como más conforme a ella, profeso y deseo morir bajo el sistema de gobierno republicano, y protesto contra el tiránico y despótico gobierno de monarquía absoluta, como el de España"57, para incidir con especial interés a sus obras El triunfo de la libertad contra el despotismo y el Catecismo religioso politico contra el real catecismo de Fernando VII. Obra esta última perdida, de la que no se conserva más que el prospecto que rescató Pedro Grases ${ }^{58}$, un artículo titulado "Catecismo" que data de 1819.

Puede sorprender la decisión de Roscio de hacer un catecismo pero todavía perduraban en España y América. Nacidos con una especial retórica en época de la Revolución francesa contenían "nuevas formas simbólicas de la praxis política" 59 con fines didácticos y de propaganda por parte de los ilustrados y destinados al grueso de la población. Aunque la época de esplendor de los catecismos corresponde a "periodos anteriores de Fernando VII y en los constitucionales de su reinado, pero [fueron] en progresiva decadencia tras su muerte, cuando se vieron aquellos desplazados por la prensa diaria de uno u otro signo

55 Ibid., 106.

56 Ibid., 128. Frases como estas de la homilía apoyaban las ideas de Roscio: "No creáis que ella choca a la forma de gobierno democrático. Viviendo en él unidos a vuestro Divino Salvador, podréis vosotros concebir una justa esperanza de vuestra salud eterna: podréis vosotros, obrando vuestra felicidad temporal, y la de vuestros hermanos, obrar la gloria de la República y de las autoridades que la rigen" y aún más: "sed cristianos todos, y vosotros seréis excelentes demócratas" (Ibid., 130).

57 Ibid., 136.

58 El artículo "Catecismo" de Roscio se publicó por primera vez en Angostura, en el Correo del Orinoco, números 32 y 33, 22 de mayo y 7 de junio de 1819 .

59 C. Álvarez Alonso, "Catecismos políticos de la primera etapa liberal española” en P. Fernández Albadalejo y M. Ortega López, eds., Antiguo Régimen y liberalismo. Homenaje a Miguel Artola. 3. Política y cultura, Madrid, Alianza Editorial, 1995, 23. 
político" ${ }^{60}$. Frente a los catecismos franceses, en los españoles es corriente el uso de referencias religiosas católicas que empleaban tanto los serviles como los liberales, en un caso para reforzar una ideología y en el segundo para implantar un nuevo pensamiento. "Desde España, el prototipo arraigó en las colonias, y todavía en 1833, cuando este género parece abandonarse en la Península por la alternativa que presenta la prensa periódica, aparecen en países como México"61. En cualquier caso este fenómeno responde a una burguesía revolucionaria y al derecho de libertad de opinión que establecía la Declaración de Derechos del Hombre y del Ciudadano de 1789.

Tal y como señala Pedro Grases, el Catecismo perdido de Roscio estaba en relación con el plan trazado en sus obras precedentes, tanto El triunfo de la libertad sobre el despotismo como la Homilía del Cardenal Chiaramonti, y puede afirmarse que se redactó "en la misma época en que escribió la referida réplica a Pío VII, o sea, en 1817 en Filadelfia [ya que] Lo concibe como oposición al Real Catecismo de Fernando VII, que se publicó en España en 1816"62, del que había tenido noticia a través de la prensa inglesa según declara en el mismo artículo copiando incluso un irónico párrafo de la misma. Este texto que Roscio publicó en 1819 puede considerarse como un resumen intencionado en el que proyecta trasmitir toda una serie de datos de la facción partidaria del poder real absoluto, apoyándose en el comienzo en el ataque a los obispos que elaboraron y difundieron el Real Catecismo de Fernando VII, como el obispo de Badajoz, Mateo Delgado Moreno y otros varios, sin olvidar un velado pero expresivo y razonado ataque a Manuel Vicente de Maya ${ }^{63}$, y una amplia serie de referencias a publicaciones partidarias del despotismo del monarca: "Son innumerables los impresos que salían de la Corte y demás prensas filiales contra la libertad nacional. Parecía que las cartas del P. Cádiz deberían cerrar la feria de estos escritos"64, ironiza Roscio.

En su correspondencia de los años posteriores el prócer venezolano alude de nuevo al tema, aunque la fecha de 1820 con el comienzo del trienio liberal supondrá un replanteamiento de la situación. En carta al general Francisco de Paula Santander, desde Angostura, el 5 de mayo de 1820 se refiere a la rebelión de los liberales en España y razona sobre los beneficios que puede tener para la independencia en los tiempos presentes: "Por fortuna la actual revolución de España ha desarmado a los clérigos y frailes ignorantes y fanáticos; ya no podrán predicar, escribir ni susurrar en el confesionario, diciendo y enseñando que pecamos en nuestra revolución, y en la lucha por nuestra independencia y libertad" 65 ;

60 Ibid.

61 Ibid., 25.

62 P. Grases, "El 'Catecismo religioso político' del Doctor Juan Germán Roscio," Revista Nacional de Cultura, Separata del no 161, Caracas, Ediciones del Ministerio de Educación, 1964, 10

63 Ibid., 13-14.

64 Ibid., 17.

65 Roscio, 1953, op. cit., III, 170. Ideas parecidas expresa en carta a Francisco Carabaño, Angostura, 17 de julio de 1820, donde vuelve a hablar de la satisfacción del triunfo liberal en España 
así como en otra carta al mismo interlocutor, también desde Angostura, el 27 de septiembre de 1820, se muestra optimista respecto al próximo triunfo de la revolución aunque se hace eco de las dificultades, "La España nos ha hostilizado con gente americana, con provisiones americanas, con caballos americanos, con frailes y clérigos americanos, y con TODO americano" ${ }^{66}$ dice en alusión a los criollos que formaban parte de los ejércitos realistas.

Entre las cartas a Bolívar dedicadas, sobre todo, a noticias de tipo militar y político, escritas desde Angostura, se destacan la del 2 de agosto y la del 3 de septiembre de 1820, en la que da noticias de cómo se han impreso en Venezuela las cartas contra el Abate de Pradt:

También se han impreso en Caracas las cartas del Indio contra el Abate de Pradt, sosteniendo la perpetua dependencia de estos países del Gobierno español; son aquellas mismas cartas que Morillo encargaba a Patrullo hiciese imprimir a todo costo en los Estados Unidos. Muchos ejemplares salieron de manos de los emisarios de Morillo para esparcirlos entre los emigrados y cooperar al engaño. Son anónimas las tales cartas, escritas por algún español que se finge indio puro de estas Indias para mejor engañar ${ }^{67}$.

Y en la segunda carta vuelve a insistir, esta vez comparando el éxito de la publicación con su catecismo todavía inédito: "Muchos suscritores ha tenido la impresión o reimpresión en Caracas de las cartas que se dicen escritas por un indio al Abate De Pradt; y el Catecismo cristiano político contra el Real Catecismo de Fernando VII, anunciado en nuestra Gaceta desde el año pasado, no ha tenido siquiera un suscritor, ni uno que ofrezca siquiera una manilla de papel para su impresión" ${ }^{68}$, aunque añade a continuación que el cambio liberal en España ha hecho menos urgente su publicación porque los acontecimientos han desvirtuado la propaganda absolutista. La queja del prócer venezolano tiene algún sentido en sí misma y, sobre todo, porque nos ha impedido conocer esa curiosa obra en un momento en que la propaganda sobre la emancipación de los países levantaba pasiones en uno y otro lado del mar. Estos son los casos del francés Abate de Pradt (1759-1837) y también del español Juan Antonio Llorente (1756-1823). Tanto uno como otro "exhortaron a los americanos a independizarse de Roma, creando iglesias nacionales basadas en constituciones religiosas establecidas por los gobiernos civiles"69. Por una parte Llorente publica Discursos sobre una Constitución Religiosa, considerada como parte de la civil nacional,

y le dice a su corresponsal que entonces era diputado por Venezuela en España, que le envía un ejemplar de su libro y otro para el Obispo de Cádiz, "para que si es susceptible de enmienda, no incurra en los errores que procuraba desacreditar la noble revolución de los liberales" (115).

66 Ibid., 168.

67 Ibid., 135.

68 Ibid., 164.

69 Martí Gilabert, op. cit., 178. 
París $1820^{70}$, por otro el Abate de Pradt ${ }^{71}$ se erigió en Europa como el "paladín máximo" de la emancipación hispanoamericana al decir de Aguirre Elorriaga ${ }^{72}$ e influyó en el pensamiento de esta época en los países de América. Obras suyas como Antídoto al Congreso de Rastadt (1798), en uno de cuyos apartados analiza el proceso de la emancipación de las colonias, resulta ser el antecedente de otra obra suya más difundida, Las tres edades de las colonias (1802), cuyo capítulo más interesante es "Hipótesis diversas sobre el modo de separación de las colonias de sus Metrópolis", donde expone cuatro formas de emancipación. Su relación con Napoleón sufrió algunos altibajos, con lo que al enfrentarse al gobierno francés que ridiculizaba sus teorías americanistas "le ganaba en América las simpatías de perseguido defensor de la causa"73. De hecho Bolívar se carteó con él, y su doctrina tuvo alguna incidencia en sus escritos.

En contra de las teorías del abate, sobre todo las expuestas en Des Colonies et de la révolution actuelle de l'Amérique (Paris, F. Béchet, 1817) surgieron respuestas varias, entre ellas la publicación Cartas al Abate De Pradt aparecidas anónimamente en 1818 en francés, pero que pronto fueron atribuidas al cónsul español en Ámsterdam, Santiago Jonama ${ }^{74}$. Aguirre Elorriaga localizó un largo memorial de este cónsul español, fechado en 1818, en el que el autor adjunta una carta al rey Fernando VII, encontrada en el Archivo de la Embajada española ante la Santa Sede, en la que Santiago Jonama se duele de la difusión de la obra de De Pradt por toda Europa, lo que confirma también su autoría:

Las Cartas al Sr. de Pradt tuvieron una difusión correspondiente a los deseos manifestados por el Rey. El General en Jefe del Ejército expedicionario de Costa Firme, Don Pablo Morillo, las hizo traducir en Caracas por el implacable y virulento impugnador y condiscípulo de Bolívar, Don José Domingo Díaz. Apareció

70 E1 título completo es: Discursos sobre una constitución religiosa, considerada como parte de la civil nacional / Su autor Un Americano; los da á luz D. Juan Antonio Llorente... Paris: Imprenta de Stahl, 1820. Véase Aguirre Elorriaga (133-136).

71 Dominique Dufour de Pradt, clérigo ilustrado, se incorpora a la corte de Napoleón donde su pensamiento influyó con fuerza en su época. Su obra Las tres edades de las colonias, o su estado pasado, presente y futuro (1801) que se parte de las ideas de Raynal, tuvo una gran difusión en América. En 1804 actuó como maestro de ceremonias en la coronación de Napoleón, donde lo vio Bolívar; en 1808 se le designó Arzobispo de Malinas. Participó en el Tratado de Bayona, en contradicción con su doctrina, para apoyar en la abdicación. Napoleón desconfía de él a partir de 1810. También recibió con entusiasmo el triunfo liberal de 1820 y redactó La Revolución actual de España y sus consecuencias (1820) en la que instaba a la emancipación.

72 M. Aguirre Elorriaga, El abate De Pradt en la emancipación hispanoamericana (1800-1830), Caracas, Universidad Católica Andrés Bello, 1983, 55.

73 Ibid., 101.

74 Primera edición: Lettres à M. l'Abbé de Pradt. Par un indigène de l'Amérique du Sud, Paris, Chez Rodriguez, 1818. Reflexiones sobre el estado actual de la América, o Cartas al Abate de Pradt, escritas en francés por un natural de la América del Sur, y traducidas al castellano por D. Antonio de Frutos Tejero, presbitero, doctor en sagrada teología, y médico penitenciario de los reales hospitales General y Pasión de esta corte. Madrid, Imprenta de Burgos, 1820. 
la traducción en Caracas en 1819, y fue reimpresa en Madrid en 1829. Pero antes de 1829 ya corría por España una nueva traducción de Don Antonio Frutos Tejero, 1820, lujosamente editada en la Corte, sin duda a expensas regias ${ }^{75}$.

Ideas del Abate influyeron en el pensamiento de la época, como "la teoría de la mayoria de edad de las colonias, que hemos visto aceptada por su propio impugnador Sr. Jonama; la persuasión de que la libertad hispanoamericana era la salvación económica de Europa y particularmente de Francia; y el proyecto de un Congreso Colonial"76. Este último proyecto consistía en que las cinco potencias, Rusia, Prusia, Austria, Inglaterra y Francia se interpusieran entre las colonias sublevadas y España, algo que se discutió en la reunión de Aquisgrán de 1819 donde Richelieu defendió el proyecto fracasado de la creación de monarquías constitucionales en América. Estas ideas del Abate las discutirá Jonama en las ocho cartas de su libro ${ }^{77}$ para concluir que "Lo que la España debe hacer es conservar la posesión plena y entera de sus colonias. Esto no es solamente un derecho, sino que también es una obligación por su parte"78. Aunque las cartas de Jonama son analíticas y con cierto tono moderado, es lógico que Roscio se hiciera eco con detalle de la difusión de semejante obra que cimentaba el poder absolutista en los dominios americanos.

Como apunte final de este recorrido que no agota las referencias antiliberales en los escritos de Roscio, es preciso añadir la estrategia que el prócer venezolano le propone a Bolívar en carta de 27 de septiembre de 1820 para que consiga "comunicaciones papales" como instrumento más eficaz de atraerse a los americanos que siguen el las filas realistas. "Un Breve Pontificio de relaciones con nosotros haría lo que no ha sido dado a un decenio de contiendas y sacrificios por la emancipación y libertad"79. Su autor seguía siendo muy consciente en su último año de vida del poder de la Iglesia y de cómo, cualquier gesto contrario a su poder sería de consecuencias muy negativas. Una noticia le da a Bolívar, acerca del establecimiento de una logia de francmasones en la zona que podría despertar las iras del poder religioso porque "los mismos enemigos nos tildarán de impíos, herejes, etc., y retraerán de la conversión a los hermanos americanos que hallan en su partido" ${ }^{80}$. Incluso en el mismo lugar cita como ejemplo el escándalo de ciertos versos satíricos y anticlericales que "en Cádiz corrieron con aprobación insertos en el periódico La abeja española, el año 1813”" Tales versos pueden ser los que

75 Aguirre Elorriaga, op. cit., 104-105.

76 Ibid., 106.

77 Véase Gil Novales en S. Jonama, Cartas al Abate de Pradt. Por un indigena de la América del Sur, edición crítica de A. Gil Novales, Antoni Bosch/Instituto de Cooperación Iberoamericana, 1992, XII-XXI, donde hace un análisis de las ideas expuestas por el autor.

78 Ibid., 80.

79 Roscio 1953, op. cit., III, 173.

80 Ibid., 174.

81 Ibid. 
aparecen en el número 351 de la misma publicación el sábado 28 de agosto de 1813 con el título de "Romance": "Vengan frayles, vayan frayles; / Que los haya, y no los haya; / Que vuelvan, y que no vuelvan, / Coman bien, o coman nada. / Que se pongan los conventos, / Y que vuelvan las pitanzas; / Que queden, y que no queden; / Se compongan, o se caigan. / Que se les dé un asignado./ ¡Señor, que no se les paga! / Pues váyanse a los conventos/Y allí cobrarán sin falta”. O bien el que lleva como título "Artículo comunicado" del lunes 19 de julio donde se satiriza la laxitud moral del clero ante los poderoso y su rigor con los liberales ${ }^{82}$. Valgan estos dos ejemplos como conclusión para evidenciar una vez más la relación persistente entre los liberales de uno y otro lado del Atlántico.

\section{BIBLIOGRAFÍA}

Aguirre Elorriaga, M., El abate De Pradt en la emancipación hispanoamericana (18001830), Caracas, Universidad Católica Andrés Bello, 1983.

Álvarez Alonso, C., "Catecismos políticos de la primera etapa liberal española" en P. Fernández Albadalejo y M. Ortega López, eds., Antiguo Régimen y liberalismo. Homenaje a Miguel Artola. 3. Politica y cultura, Madrid, Alianza Editorial, 1995, 23-35.

Grases, P., "El 'Catecismo religioso político' del Doctor Juan Germán Roscio," Revista Nacional de Cultura, Separata del no 161, Caracas, Ediciones del Ministerio de Educación, 1964.

Herrero, J., Los orígenes del pensamiento reaccionario español, Madrid, Alianza Editorial, 1994.

Jonama, S., Cartas al Abate de Pradt. Por un indigena de la América del Sur, edición crítica de A. Gil Novales, Antoni Bosch/Instituto de Cooperación Iberoamericana, 1992.

López-Cordón Cortezo, M. V., "Predicación e inducción política en el siglo XVIII: Fray Diego José de Cádiz”, Hispania, 138, enero-abril 1978, 71-119.

Martí Gilabert, F., Iglesia y Estado en el reinado de Fernando VII, Pamplona, EUNSA, 1994.

Moliner, A., "El antiliberalismo eclesiástico en la primera restauración absolutista (1814-1820)" en Hispania Nova, revista de Historia Contemporánea, 3, 2003, http:// hispanianova.rediris.es/articulos/03_012.htm.

Pensamiento politico de la emancipación venezolana, compilación, prólogo y cronología de P. Grases, Caracas, Biblioteca Ayacucho, 1988.

Peñas Bernaldo de Quirós, J. C., "El pensamiento reaccionario en las Cortes de Cádiz", en P. Fernández Albadalejo y M. Ortega López, eds., Antiguo Régimen y liberalismo. Homenaje a Miguel Artola. 3. Política y cultura, Madrid, Alianza Editorial, 1995, 539-550.

Revuelta González, M., "El anticlericalismo español en el siglo XIX" en Religión y sociedad en España (siglos XIX y XX), Madrid, Casa de Velázquez, 2002, 155-178.

Romero GonZÁlez, J., "El sermonario gaditano en la segunda mitad del siglo XVIII. Una sociedad en cambio" en P. Fernández Albadalejo y M. Ortega López, eds.,

82 Véase "Romance" en Abeja española [Cádiz] número 351, sábado 28 de agosto de 1813,221223; y “Artículo comunicado" en Abeja española, número 311, lunes, 19 de julio de 1813, 149-154. 
Antiguo Régimen y liberalismo. Homenaje a Miguel Artola. 3. Politica y cultura, Madrid, Alianza Editorial, 1995, 611-618.

Roscio, J. G., Obras, 3 vols., prólogo de A. Mijares, compilación de P. Grases, Caracas, Publicaciones de la Secretaría General de la décima Conferencia Interamericana, 1953.

-, El triunfo de la libertad sobre el despotismo, prólogo, cronología y bibliografía de D. Miliani, Caracas, Biblioteca Ayacucho, 1996.

Sarrailh, J., La España ilustrada de la segunda mitad del siglo XVIII, México/Buenos Aires, Fondo de Cultura Económica, 1957.

Teruel Gregorio de Tejada, M., Obispos liberales. La utopía de un proyecto (18201823), Lleida, Editorial Milenio, 1996. 